\section{Origin and spread of AIDS}

SIR-The recent report ${ }^{1}$ of the detection of HIV-1 sequences in the tissues of a British sailor who died in Manchester in 1959 highlights again the question of when HIV first infected human beings. The same year is also that of the earliest recorded serum samples (from Zaire) found to contain antibodies against HIV-1 (ref. 2). The earliest case of HIV-1 positive serum outside Africa, reported from Norway", it was that of a sailor who probably became infected in the mid-1960s and whose wife and third daughter died of what would be diagnosed today as AIDS.

There is now little doubt human AIDS began in Africa. Not only is the disease widely spread in central Africa, but only in Africa are there monkey species naturally infected with lentiviruses related to $\mathrm{HIV}^{4}$. Although the first such virus was isolated from a macaque (and therefore named SIV $_{\mathrm{MAC}}$ ), that animal was probably infected in captivity with $\operatorname{SIV}_{\text {SMM }}{ }^{\circ}$, for which the African sooty mangabey monkey (SMM) is the natural host.

It remains a puzzle that the two human viruses known to cause AIDS (HIV-1 and HIV-2, the latter isolated from a West African patient ${ }^{7.8}$ ) share only 40 per cent homology while HIV-2 and both strains of SIV share roughly 75 per cent homology", and an extra gene $v p x$ which probably arose as a duplication of the vpr gene $\mathrm{g}^{\mathrm{li}}$. These similarities explain both the serological cross-reactivity of SIV and HIV-2 and the circumstances that HIV-2 was recognized" after an AIDS patient's serum failed to react against HIV-1.

The first plausible explanation for the origin of AIDS by cross-species transfer is due to Noireau in 1987 (ref. 11). He referred to a book published by Anicent Kashamura $^{12}$, a member of the Idjwi tribe of the Lake Kivu region in East Zaire. Kashamura deals with the sexual habits of the people of the large African lakes. Noireau quotes the following sentence "To stimulate a man or a woman and induce them to intense sexual activity, male monkey blood for a man or shemonkey blood for a woman, was directly inoculated in the pubic area and also into the thighs and back." Such practices would constitute an efficient means of trans-species transmission and could be responsible for the emergence of SIV infections of man and thus AIDS.

This led to the suggestion ${ }^{13}$ that SIV $_{\text {MArssm }}$ could have given rise to HIV-2 infection of man in West Africa and that a distinct monkey virus will eventually be isolated which will be similar to HIV-1. The complete nucleotide sequence of a lentivirus recently isolated from a chimpanzee has indeed revealed what has been described" as "the missing link".

Obviously, it is not possible to estimate when the first person became infected with a monkey lentivirus, but the question of when and how the present epidemic began to spread is more tractable. Extensive European contacts with black Africa go back five centuries, accompanied by the forceful transfer of millions of Africans to the New World. Arabs similarly had contact with West and East Africa over a span of hundreds of years and also engaged in slave traffic. Yet there is no evidence for the existence of HIV in Europe, the Americas or Arabia during the past century or even the first half of this century, which argues strongly that the widespread HIV infection in Africa is a recent event ${ }^{1 \mathrm{t}}$.

The wide divergence between isolates of HIV-1 and of HIV-2 can then be explained by continuous mutation and infection by SIV from different species of monkeys. Studies of the spread of adult T-cell leukaemia virus (ATLV/HTLV-1) indirectly bear on this question. ATLV was first shown to be the cause of ATL in Japan ${ }^{17}$, which was subsequently shown also to be prevalent in parts of Africa ${ }^{18}$. Infection with ATLV is uncommon in the West, where most infected individuals are either Japanese or blacks of African origin. So it is not unreasonable to think that ATLV was brought to the West first with the African slave trade and subsequently by Japanese migration to the Americas (United States and Brazil). Unlike. HIV, ATLV is not readily transmissible and has not spread widely in the West, but the finding of ATL and its virus among British blacks indicates two transcontinental transfers - from Africa to the New World and from the West Indies to Britain". Although infection with HIV is now prevalent in the West Indies, its absence in immigrants to Britain from the Caribbean 40 years ago supports the notion that the virus started spreading to the West Indies more recently.

All in all, the epidemiological evidence thus points to the spread of HIV infection from Africa since the Second World War. The spread seems to coincide with the widespread introduction of syringes and needles from the West, together with vaccination programmes. Syringes arrived together with antibiotics: as the early generation of antibiotics came only as injectable medicines, the needle and syringe became an inseparable from their therapeutic effect. Even now, injectable medication is the treatment of choice in Africa and other countries.

One can readily then envisage that a handful of individuals in Africa somehow became infected with monkey lentiviruses and subsequently transferred the virus to others. This 'syringe and needle' period coincided with improved communication and extensive migration in Africa. Thus the virus would have been carried from a few isolated rural endemic areas into urban populations, and thence by sexual contacts overseas.

AIDS readily spreads by syringes as seen in drug users and by recent experience in the Soviet Union and Romania. It is also noteworthy that HIV is not the first monkey virus to infect man: in 1934, Sabin and Wright reported the isolation of herpesvirus simiae ( $B$ virus) from the brain of a laboratory worker dead after a bite by an apparently normal macaque rheus mon$\mathrm{key}^{211}$. Since then, there have been more than a dozen such cases. Herpesvirus simiae seems to be the counterpart, in macques, to herpes simplex in humans; infection is latent and benign. But, on transfer to man, herpesvirus simiae is fatal, and quickly.

Lentiviruses in the African monkeys which are their natural hosts may be similar - the virus becomes deadly only after transmission to another species, in this case man. The significant difference is that the latency period between infection and disease is longer, about 10 years on the average, providing opportunities for spread before the infected person dies.

That is why the outlook is so gloomy. With such a long latency period for HIV and in the absence of an effective drug or vaccine, the spread of infection seems incxorable. Already AIDS is the leading cause of death among women aged 20-40 in the United States and Western Europe $^{21}$. Unless efforts to halt the spread of AIDS succeed, it can only be a matter of time before AIDS is as prevalent in the rest of the world as it is now in some regions of Africa.

Department of Haematology,

A. KARPAS

University of Cambridge,

MRC Centre, Hills Road,

Cambridge CB2 $2 \mathrm{QH}$, UK

1. Corbit, G., Bailey, A. \& Williams G. Lancet 336, 51 (1990).

2. Huminer, D., Rosenfeld, J.B. \& Pitlik, S.D. Rev. Infect. Ois. 9, 1102-1108 (1987).

3. Froland, S. et al. Lanceti. 1344-1345 (1988).

4. Ohta, Y. et al. Int. J. Cancer 41, 115-122 (1988)

5. Daniel, M.D. et al. Science 228, 1201-1204 (1985)

6. Fultz, P. et al. Proc. natn. Acad. Sci. U.S.A. 83. 52865290 (1980).

Clavel, F. et al. Science 233, 343-346 (1986).

8. Guyader, M. et al. Nature 326, 602-609 (1987)

9. Chakrabake., L. et al. Nature 328, 543-547 (1987)

10. Tristem, M., Marshall, G., Karpas, A., Petrik, J.\& Hill, F. Nature 347, 341-342 (1980)

11. Noireau, F, Lanceti, 1498 (1987)

12. Kashamura, A. Famille Séxuàlite et culture (Payot, Paris, 1973).

13. Karpas, A. New Scient. No. 1569, 67 (1987)

14. Huet, T., Cheynier, R., Meyerhaus, A., Roelands, G. \& Wain-Hobson, S. Nature 345, 356-359 (1990)

15. Desrosiers. R.C. Nature 345, 288-289 (1990)

16. Smith, T.F., Srinivasan, A., Schoctatman, G., Marcus, M. \& Myers, G. Nature 333, 573-575 (1988).

17. Hinuma, Y. et al. Proc. natn. Acad. Sci. U.S.A. 78 $6476-6480(1981)$

18. Hunsmann, G., Schneider, J., \& Yamamoto, J., Int. J. Cancer 32, 329-332 (1983)

19. Karpas, A. Malik, K. \& Lida, J. Archs Virol 95, 237-249 (1987).

20. Sabin, A. \&Wright, A. J. exp. Med. 69, 115 (1934)

21. Chin, J. Lancet ii, 221-224 (1990). 